\title{
Prenatal expression of interleukin $1 \beta$ and interleukin 6 in the rat pituitary gland
}

\author{
J.A. Moro ${ }^{\text {a }}$ J. Carretero ${ }^{\text {b }}$, M.I. Alonso ${ }^{\text {a }}$, C. Martín ${ }^{a}$, A. Gato ${ }^{\text {a }}$, A. de la Mano ${ }^{\mathrm{a}, *}$ \\ a Departamento de Anatomía y Radiología, Facultad de Medicina, Universidad de Valladolid, C/Ramón y Cajal 7-47005-Valladolid, Spain \\ ${ }^{\mathrm{b}}$ Departamento de Anatomía Humana e Histología, Laboratorio de Neuroendocrinología, Instituto de Neurociencias de Castilla y León, Facultad de Medicina, \\ Universidad de Salamanca, Avda. Alfonso X el Sabio, s/n-37007-Salamanca, Spain
}

\section{A R T I C L E I N F O}

\section{Article history:}

Received 4 February 2008

Received in revised form 22 July 2008

Accepted 5 August 2008

Available online $\mathrm{xxxx}$

\section{Keywords:}

Hypophysis

Development

Cytokine

Immunocytochemistry

Western-blot

\begin{abstract}
A B S T R A C T
It is known that interleukin $1 \beta$ (IL-1 $\beta$ ) and interleukin 6 (IL-6) are expressed post-natally in normal and tumoral cells in the anterior pituitary, and that they play a role in both the liberation of different hormones and in the growth, proliferation and tumor formation of the pituitary gland. However, their expression and role during embryonic and fetal development remain unknown. We have performed an immunocytochemistry study of prenatal expression and distribution of IL- $1 \beta$ and IL- 6 in isolated embryonic rat Rathke's pouch prior to birth, more specifically between 13.5 and 19.5 days p.c. Western-blot analysis carried out on 19.5-day p.c. embryos showed positive immunolabelling for IL-1 $\beta$ and IL-6. These interleukins were initially expressed simultaneously in the rostral and ventral portions of Rathke's pouch in 15.5-day p.c. embryos, and this expression progressed caudodorsally in later developmental stages, extending to most of the hypophysis before birth. The number of cells expressing these interleukins increased throughout this period: $48.22 \%$ of anterior pituitary cells expressed IL-6 in 19.5-day embryos, whilst IL- $1 \beta$ was positive in $39.8 \%$ of the cells. Moreover, we have demonstrated that some adenohypophyseal cells co-express both interleukins. Such findings represent the first step towards an understanding of the physiological role of these interleukins in anterior pituitary development.
\end{abstract}

(c) 2008 Elsevier Ltd. All rights reserved.

\section{Introduction}

\subsection{Development of the adenohypophysis in rat}

Adenohypophysis (anterior, intermediate and tuberal lobes of the pituitary gland) develops from the Rathke's pouch as an invagination of the epithelium in the roof of the stomatodaeum (primitive buccal cavity), which will isolate from it at 13-13.5 days postcoitum (p.c.). The Rathke's pouch will contact with the floor of the diencephalon, inducing the formation of the neurohypophysis (pars nervosa) and the infundibulum (pituitary stalk). The ventral wall of the Rathke's pouch undergoes intense growth, forming the pars anterior (anterior lobe) of the adenohypophysis; subsequently, dorsal and lateral prolongations or wings develop on each side, which reach the pituitary stalk and will form the pars tuberalis (tuberal lobe); following this, the dorsal wall of the Rathke's pouch undergoes small-scale cellular proliferation, with the formation of the pars intermedia (intermediate lobe) of the adenohypophysis.

\footnotetext{
* Corresponding author. Fax: +34 983423022.

E-mail addresses: moro@med.uva.es (J.A. Moro), jcar@usal.es (J. Carretero), mialonso@med.uva.es (M.I. Alonso),gato@med.uva.es (A. Gato), alamano@ah.uva.es (A. de la Mano).
}

1.2. Interleukin expression and function in normal and tumoral adult pituitary cells

Interleukins are multifunctional peptides produced by many different types of cells and tissues, including principally the immune and endocrine systems. Numerous studies, employing immunocytochemistry, mRNA detection and "in situ" hybridization, have shown that interleukin $1 \beta$ (IL-1 $\beta$ ), interleukin 6 (IL-6) and their receptors are expressed in normal adenohypophysis cells in different species of animals. It has been demonstrated that IL-1 $\beta$ is diffusely expressed in pituitary cells of the anterior lobe of the hypophysis, especially in TSH-secreting cells [1-3], and that IL-6 is localized in ACTH, gonadotropin, GH and PRL-secreting cells, as well as in folliculo-stellate cells (non-secreting cells) [4,5]. In addition, the IL-1 receptor type1 (IL-1R1) has been detected in cells from the anterior lobe of the pituitary gland [6,7], mainly in $\mathrm{GH}-$ secreting cells and, to a lesser extent, in PRL and ACTH-secreting cells [8]. The receptors for IL-6 have also been detected in normal pituitary cells, specifically in GH, FSH-LH, PRL and ACTH-secreting cells $[4,9,10]$.

Cytokines could also be involved in pituitary cellular proliferation and growth [11]. It seems that IL-1 $\beta$ and IL-6 inhibit the growth of normal rat pituitary cells, but both cytokines and their receptors have been shown to exist in different cell lines in pituitary adenomas $[4,9,12,13]$, which could be indicative of their 
involvement in pituitary gland tumor formation [14-16]. Although IL-1 $\beta$ does not seem to be directly related to pituitary tumorogenesis [13], it has been demonstrated that IL-6 is involved in the development of diverse pituitary adenomas [14,15,17-19].

Regarding the physiological role of cytokines in the adenohypophysis, it is believed that some interleukins may have a role to play in the release of certain pituitary hormones $[2,20]$; in this regard, we know that peripheral administration of IL-1 $\beta$, IL-2 and IL6 increases plasma levels of ACTH $[1,21,22]$, whilst central administration of IL-1 $\beta$ produces intense inhibition of pituitary secretion of LH and FSH [23,24]; similarly, IL-6 stimulates PRL, GH, FSH and LH liberation in cell cultures of rat pituitary cells $[25,26]$ and might contribute to excessive $\mathrm{GH}$ production in the majority of somatotroph adenomas [27].

\subsection{Interleukin expression and function during embryonic development}

Despite both our knowledge of cytokine expression in the anterior pituitary and, as previously mentioned, the abundant data relating to its functional role, most studies concern the post-natal period, with little information relating to the possible role of interleukins in adenohypophyseal development during the embryonic and fetal periods. Nowadays it is known that several interleukins are expressed in normal embryonic cells at very early stages of development [28-30]; we have previously demonstrated that IL$1 \beta$ is expressed in the neuroepithelium of the embryonic spinal cord and stimulates proliferation and differentiation in these cells [31]. Moreover, receptors for IL- 6 and IL- 8 have been detected in numerous tissues and organs in human foetuses [32]. The expression of receptors for the Leukemia Inhibitor Factor (LIF), IL-6 and of the subunit gp130 in human fetal pituitary tissue between 18 and 31 weeks of gestation has been demonstrated [33], and it has also been shown that LIF and IL-6 stimulate ACTH and GH secretion in primary cultures of human fetal adenohypophyseal cells. Furthermore, when the subunit gp130 was blocked by antibodies, the levels of ACTH dropped below basal values, indicating that LIF and IL6 may be involved in regulating pituitary function during the fetal period via the same transduction signal. In addition, it has been proven that lipopolysaccharides from gram-negative bacteria induce permanent neuroendocrine changes by the liberation of both cytokines IL-1 $\beta$ and IL-6 during the prenatal $[34,35]$ and neonatal periods [36]. All of this suggests that cytokines could play a physiological role in the normal development of the anterior pituitary, and that variations in levels of interleukins during embryogenesis might disturb neuroendocrine regulating programmes, with subsequent consequences in adult life.

Given the scant knowledge concerning the possible influence of cytokines on normal pituitary development, in this paper we have employed immunocytochemistry and western-blot to investigate the chronological and topographical pattern of IL- $1 \beta$ and IL-6 expression in isolated Rathke's pouch of rat embryos until immediately prior to birth. This represents an initial step towards understanding the physiological function these interleukins may have in anterior pituitary development.

\section{Materials and methods}

\subsection{Obtaining rat embryos}

Wistar rats, stabulated at a constant temperature $\left(22^{\circ} \mathrm{C}\right)$ and with a cycle of $12 \mathrm{~h}$ of light and $12 \mathrm{~h}$ of darkness, were employed. To calculate embryonic age, day 0 referred to the morning when a copulation plug was found after overnight mating. Pregnant rats were sacrificed by ether inhalation and the embryos extracted from the uterus; the enveloping membranes were then removed and their heads processed for histology. For our study, embryos of between 13.5 days p.c.-immediately after the isolation of Rathke's pouch from the roof of the stomatodaeum-and 19.5 days p.c. were employed. Five embryos from each stage were used for immunocytochemistry (35 embryos in total).

\subsection{Immunocytochemistry}

The heads of the embryos were fixed in picric acid-paraformaldehyde [37] for $12 \mathrm{~h}$ at $4{ }^{\circ} \mathrm{C}$. Following this, the specimens were dehydrated through a graded series of ethanol and embedded in paraffin through xylene. Subsequently, we made $8 \mu \mathrm{m}$-thick serial coronal sections, which were mounted on glass slides. These were then deparaffinized, rehydrated and submerged consecutively in lugol and sodium metabisulphite in order to eliminate the fixing agent, and afterwards washed several times in PBS and the endogenous peroxidase inhibited with a solution of methanol and 3\% hydrogen peroxide for $30 \mathrm{~min}$. After several washings in PBS, the sections were incubated in PBS/BSA for $20 \mathrm{~min}$ and subsequently in the first antibody, IL-1 $\beta$ rabbit anti-rat polyclonal or IL- 6 rabbit anti-rat polyclonal (Endogen). In both cases, the conditions were the same, namely, a $1 / 100$ dilution in PBS at $4{ }^{\circ} \mathrm{C}$ (a working dilution of $10 \mu \mathrm{g} / \mathrm{ml}$ ) overnight in a humid chamber. Following washing in PBS, we proceeded to incubate with the secondary antibody-horse radish peroxidase-conjugated goat anti-rabbit IgG (Southern Biotechnology Associates, Inc.)-at a dilution of 1/ 100 in PBS, at room temperature for 90 min. After further washing in PBS, the sections were incubated with 3.3-diaminobenzidine tetrahydrochloride (DAB; Sigma) and $\mathrm{H}_{2} \mathrm{O}_{2}$ (DAB $10 \mathrm{mg} / 15 \mathrm{ml}$ in $0.05 \mathrm{M}$ Tris- $\mathrm{HCl}$ buffer, $\mathrm{pH} 7.4$, and $0.003 \% \mathrm{H}_{2} \mathrm{O}_{2}$ ). Haematoxylin was employed to counterstain the nuclei. The control sections were prepared as mentioned above in order to prove the specificity of the immunoreaction, but now using pre-immune serum instead of the primary antibody. The tissue sections were observed with a Nikon Microphot-FXA Photomicroscope and the most representative were photographed.

In order to verify whether the adenohypophyseal cells simultaneously express IL-1 $\beta$ and IL-6, we carried out a double immunolabelling on sections of 18.5 days p.c. rat embryo adenohypophysis. Fixation, dehydration, embedding and section of embryos were similar to previously described. The sections were deparaffinized, rehydrated and washed several times in PBS, and then they were incubated in a solution of primary antibodies, Rabbit anti-Rat IL$1 \beta$ polyclonal (Chemicon) and Goat anti-Rat IL-6 polyclonal (R\&D Systems), both at a final concentration of $15 \mu \mathrm{g} / \mathrm{ml}$ in PBS, at $4{ }^{\circ} \mathrm{C}$ overnight in a humid chamber. After washing several times in PBS, sections were incubated with a mixture of the secondary antibodies, Goat anti-Rabbit IgG conjugated with fluorescein isothiocyanate (FITC) (Chemicon) for IL-1 $\beta$, diluted $1 / 64$ in PBS, and Donkey anti-Goat IgG conjugated with Alexa-594 (Molecular Probes) for IL6 , diluted $1 / 1000$ in PBS. After that, sections were washed in PBS and mounted in Aquamount (Gurr). They were observed with a confocal microscope Zeiss LSM-310, and the most representative samples were photographed. Control sections were prepared as described above, but using non-immunized animal IgG instead of one of the primary antibodies (Rabbit IgG for IL- $1 \beta$ and Goat IgG for IL$6)$, and there was no cross-reaction between antibodies.

\subsection{Counting and locating the immunostained cells}

The immunostained cells for each interleukin were counted $(100 \times)$ from a total of $4000 \pm 279.29$ cells; there were 50 randomly-selected fields from the same region, with $80 \pm 5.59$ cells per field, along the whole of Rathke's pouch. Four different embryos were used for each stage studied and the data were ex- 
pressed numerically in a table, \pm standard deviation. A comparative study was made, with numerical data also reflected in a bar diagram expressing the percentage of immunomarked cells in relation to all the anterior pituitary cells.

The zone of extension of cells expressing IL- $1 \beta$ and IL- 6 was located by outlining with a light camera microscope sagittal sections of the anterior pituitary gland at the different stages studied. The areas containing cells with positive immunostaining were represented on these outlines.

\subsection{IL-1 and IL-6 Western-blot}

In all, ten 19.5-day p.c. rat embryo pituitary glands were isolated according to described methods [38] under a dissection microscope. They were subsequently placed in an Eppendorf tube and centrifuged at $5000 \mathrm{rpm}$ for $1 \mathrm{~min}$ to eliminate the supernatant; the tissue was homogenized and sonicated in order to break the cellular membranes and liberate intracytoplasmic proteins. Following this, the samples were incubated in Tris- $\mathrm{HCl} 0.25 \mathrm{M}$, $\mathrm{pH}$ 6.8, with a 6\% SDS-Tris denaturing agent and 2-mercaptoetanol for reduction. Electrophoresis was then carried out in $12 \%$ polyacrylamide gel (SDS-PAGE) with $10 \mu \mathrm{l}$ samples. Wide-range pre-stained standard protein solutions (Bio-Rad) were employed to ascertain the molecular weight. Following electrophoresis, the resulting protein bands were transferred to a nitrocellulose membrane, which was incubated in a 1\% PBS-BSA blocking solution and subsequently with the same primary antibodies used in immunoperoxidase techniques, at a dilution of $1 / 500$, in $1 \%$ PBS-BSA at $4{ }^{\circ} \mathrm{C}$ overnight. After this, the nitrocellulose membranes were washed several times in 0.1\% PBS-Tween 20 and incubated with the same second antibody used in immunoperoxidase methods, at a dilution of $1 / 500$, in $1 \%$ PBS-BSA for $1 \mathrm{~h}$ at room temperature. After several washes in PBS-Tween 20, developing was performed with Opti4-CN (Bio-Rad) according to the manufacturer's instructions, and finally the membrane was washed with bi-distilled water and left to dry for photographing.

\section{Results}

In this paper we have used immunocytochemistry and westernblot to determine the spatio-temporal expression of IL-1 $\beta$ and IL- 6 during development of the anterior pituitary gland in rat embryos; this period began with the isolation of Rathke's pouch from the roof of the stomatodaeum, at about 13.5 days p.c. up to the time shortly before birth (19.5 days p.c.). We have also quantified the number of cells expressed by these interleukins with respect to all the cells in the anterior pituitary.

\subsection{IL-1 expression}

IL-1 $\beta$ was not expressed in the anterior pituitary gland during stages $13.5-14.5$ days p.c. (Fig. $1 \mathrm{~A}$ and $\mathrm{B}$ ).

The first signs of IL-1 $\beta$ expression during anterior pituitary development in rat embryos appeared at day 15.5 p.c. (Fig. 1C and D). At this stage only a small number of cells (Fig. 4) revealed slight IL-1 $\beta$ immunostaining, predominantly located in the most rostral and ventral portions of the future pars anterior of the pituitary gland, before and beneath the cavity of Rathke's pouch (Fig. 3). During this period immunolabelling was progressively less dorsally and caudally located, with the result that little or no expression of IL-1 $\beta$ took place in the posterior region of Rathke's pouch behind the cavity (Fig. 3). The stalk of the pituitary gland and the floor of the diencephalon (the presumptive hypothalamus) also revealed IL-1 $\beta$ immunostaining from day 15.5 p.c. (not shown).

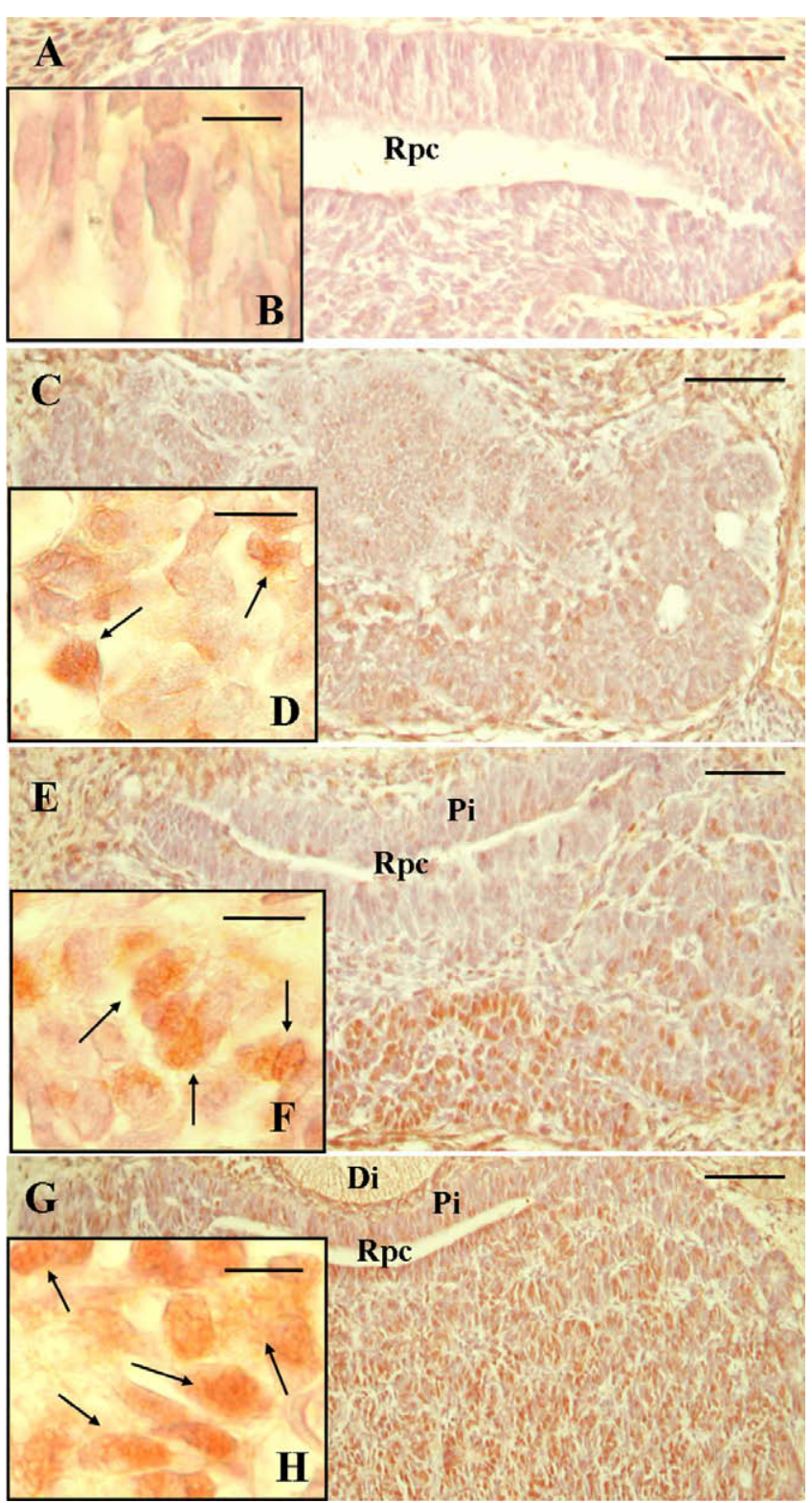

Fig. 1. Coronal histological sections of rat embryo anterior pituitary ( $A$ and $B, 13.5$ days p.c.; $C$ and D, 15.5 days p.c.; E and F, 17.5 days p.c.; G-H, 19.5 days p.c.) showing IL-1 $\beta$ immunoreactivity. DAB was used as chromogen (brown), and Haematoxylin as counterstaining. Rpc, Rathke's pouch cavity; Di, diencephalon; Pi, pars intermedia. Scale bars in A, C, E and G, $100 \mu \mathrm{m}$; in B, D, F and H, $10 \mu \mathrm{m}$.

Between stages 17.5 and 19.5 days p.c. there was a notable increase in the number of anterior pituitary cells expressing IL$1 \beta$ (Fig. 1E-H, Figs. 3 and 4), whilst IL-1 $\beta$ immunomarked cells represented almost $40 \%$ of all pituitary cells in 19.5-day p.c. embryos. At the same time, immunostaining became more intense (Fig. 1E-H), coinciding with the rapid growth of the pituitary's pars anterior, leading to the progressive obliteration of the cavity of Rathke's pouch and the formation of columns or cellular cords around the anterior pituitary vessels. Furthermore, the zone of IL-1 $\beta$ expression widened caudodorsally (Fig. 3), occupying practically the whole of the pars anterior in 19.5day p.c. embryos. At this particular time, immunostained cells, albeit barely developed, also appeared in the future pars intermedia (Fig. 1G; Fig. 3). During these stages, IL-1 $\beta$ immunostaining persisted in the infundibulum and the area of the hypothalamus. 
At all the stages studied, control sections using pre-immune serum instead of the primary antibody against IL- $1 \beta$ did not reveal any immunomarking, demonstrating the specificity of the labeling observed (data not shown).

\subsection{IL-6 expression}

IL-6 expression revealed a very similar spatio-temporal pattern to the one mentioned for IL-1 $\beta$, although in general terms the number of immunostained cells was slightly greater for this interleukin compared with all the anterior pituitary cells (Fig. 4).

Very slight IL-6 expression was also seen in 15.5-day p.c. embryos (Fig. $2 \mathrm{~A}$ and $\mathrm{B}$ ) and in the same location as IL-1 $\beta$ expression, namely, in the most ventral and rostral portions of Rathke's pouch (Fig. 3); only $7.53 \%$ of all anterior pituitary cells expressed this interleukin at this stage.

From day 15.5 onwards, the number of positive IL-6 cells increased considerably (Fig. 4), finally representing almost half the total of anterior pituitary cells in 19.5-day p.c. embryos. As with IL-1 $\beta$, IL-6 expression was displaced dorsally and caudally, occupying the whole of the pars anterior and reaching the future pars intermedia in 19.5-day embryos (Fig. 2C-F, Fig. 3); immunostaining, however, was predominantly in the ventrorostral portion of Rathke's pouch.

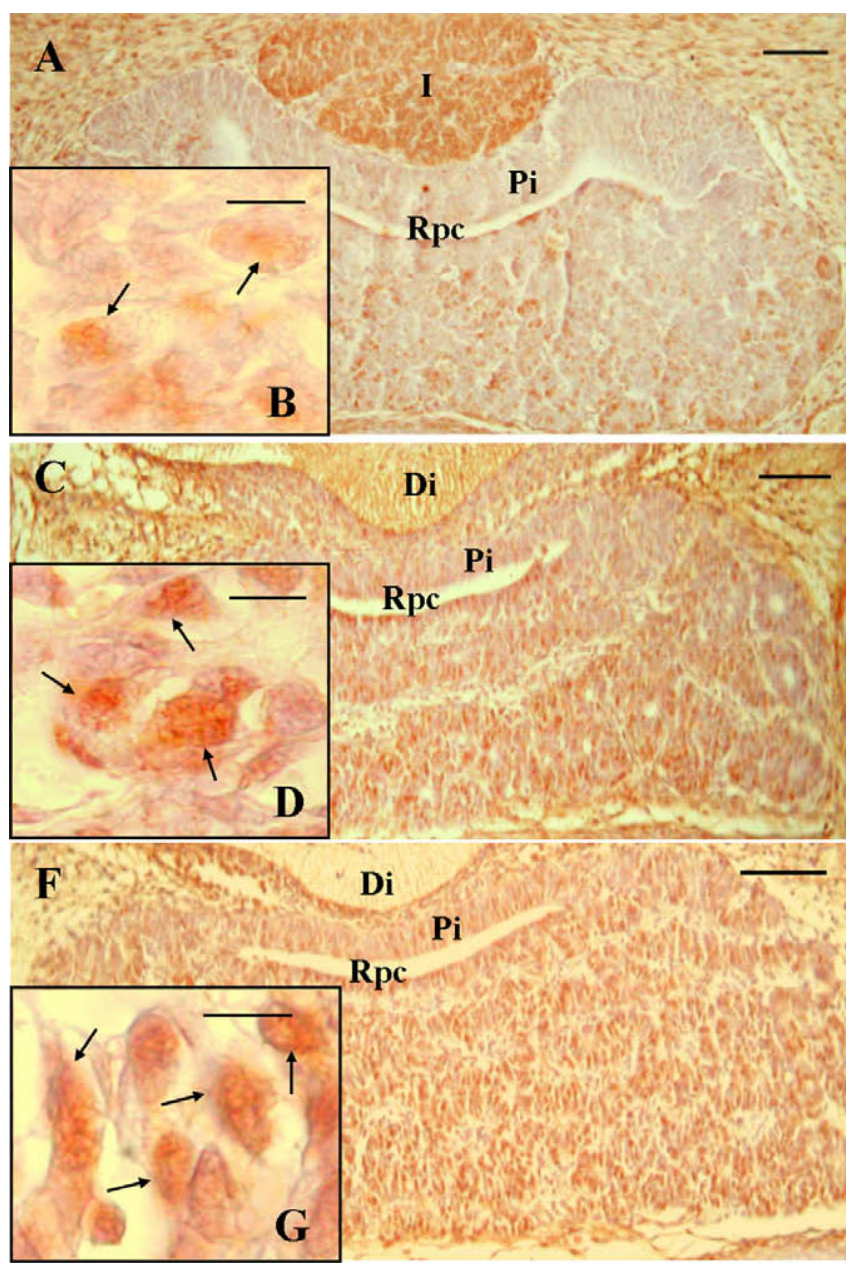

Fig. 2. Coronal histological sections of rat embryo anterior pituitary (A and $B, 15.5$ days p.c.; $C$ and $D, 17.5$ days p.c.; $E$ and F, 19.5 days p.c.) showing IL-6 immunoreactivity. DAB was used as chromogen (brown), and Haematoxylin as counterstaining. Rpc, Rathke's pouch cavity; Di, diencephalon; Pi, pars intermedia; I, infundibulum. Scale bars in A, C and E, $100 \mu \mathrm{m}$; in B, D and F, $10 \mu \mathrm{m}$.
We also observed positive IL-6 staining in the infundibulum (Fig. 2A) and on the floor of the diencephalon, in contact with Rathke's pouch (Fig. 2C and E), from day 15.5 p.c.

Control sections with pre-immune serum instead of the primary antibody against IL-6 revealed no immunolabelling (data not shown), which demonstrates the specificity of the marking observed.

\subsection{Western-blot}

In order to ascertain whether anterior pituitary IL-1 $\beta$ and IL-6 expression is specific, western-blotting was performed for both interleukins with the same antibodies as those employed in the immunocytochemistry analysis. For this test we used isolated pituitaries of 19.5-day p.c. rat embryos, the time at which both interleukins showed more intense immunostaining.

The western-blot technique revealed immunostained bands for IL-1 $\beta$ and IL-6 (Fig. 5), both between $14.4 \mathrm{kDa}$ and $21.5 \mathrm{kDa}$ in terms of the protein standards employed. In both cases, the molecular weight was within the range estimated for these interleukins $[39,40]$. There were diffuse and weak additional bands for both interleukins visible between 31 and $45 \mathrm{kDa}$, probably corresponding with their proforms.

\subsection{IL-1ßand IL-6 co-expression}

Since IL-1 $\beta$ and IL-6 show a similar spatial and temporal expression pattern, we carried out double immunolabelling by means of immunofluorescence; this would show whether there were cells in the adenohypophysis simultaneously expressing both interleukins.

In sections of 18.5-day p.c. rat embryo adenohypophysis, we observed abundant positive cells for IL- $1 \beta$ labeled with fluorescein (Fig. 6A), as well as numerous positive cells for IL-6 marked with Alexa-594 (Fig. 6B). The superposition of images of both markings on the same section showed many adenohypophyseal cells coexpressing both interleukins (Fig. 6C), which suggests that a large part of these cells simultaneously produce IL- $1 \beta$ and IL-6.

\section{Discussion}

Abundant data exists regarding the expression of different interleukins and/or their receptors in adult normal and tumoral pituitary cells, as well as their possible functional role in cellular proliferation and hormonal production and release. The expression of IL-2, IL-4, IL-8, IL-11 and IL-18, has been reported [41-48], although IL- $1 \beta$ and IL- 6 seem to play a more important functional role (see Section 1). Nevertheless, there are hardly any references to the expression of these two interleukins during the development of the adenohypophysis. For this reason, a study by means of immunostaining and western-blot was carried out to ascertain IL-1 $\beta$ and IL-6 expression during pituitary prenatal development in rat embryos, from the isolation of Rathke's pouch from the roof of the stomatodaeum, at about 13.5 days p.c. up to shortly before birth (day 19.5 p.c.). We have shown that both interleukins are initially expressed simultaneously in the most rostral and ventral portions of Rathke's pouch in 15.5-day p.c. embryos, and that this expression progresses caudodorsally at later stages of development, reaching the greater part of the anterior pituitary gland before birth. Similarly, their expression has been shown in the infundibulum and on the floor of the diencephalon (the hypothalamic area). Moreover, we have demonstrated by means of double immunolabelling that adenohypophyseal cells co-expressing both interleukins are present.

During embryonic and fetal development, pituitary cells undergo an intense proliferative process followed by a differentiation to 


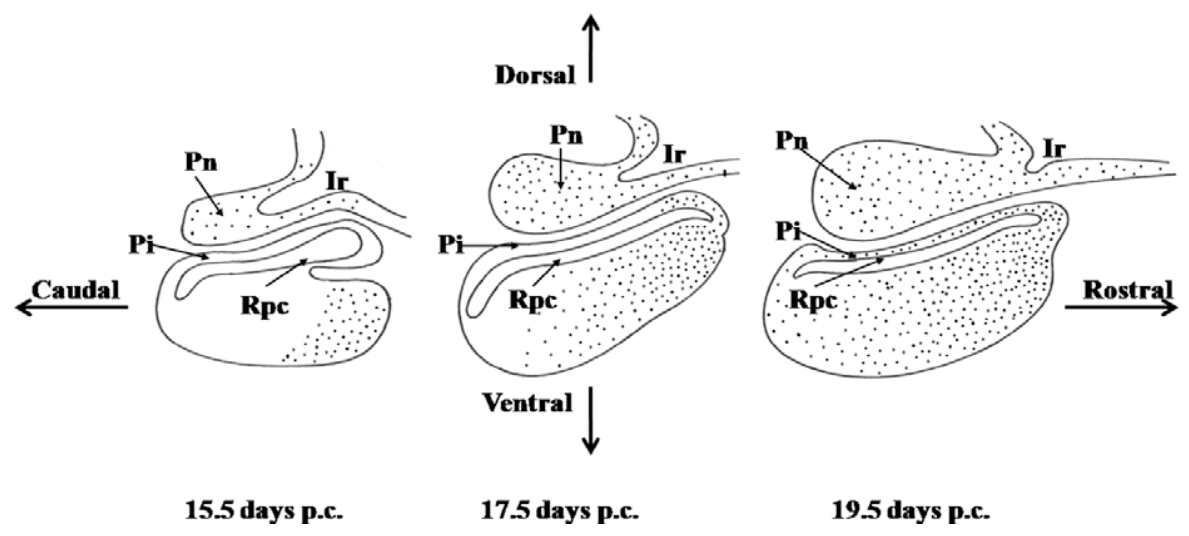

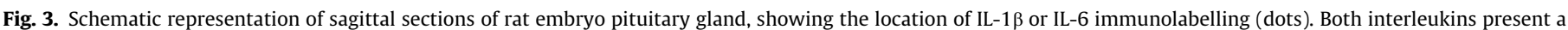
very similar temporal and spatial distribution pattern. Rpc, Rathke's pouch cavity; Ir, infundibular recess; Pi, pars intermedia; Pn, pars nervosa.

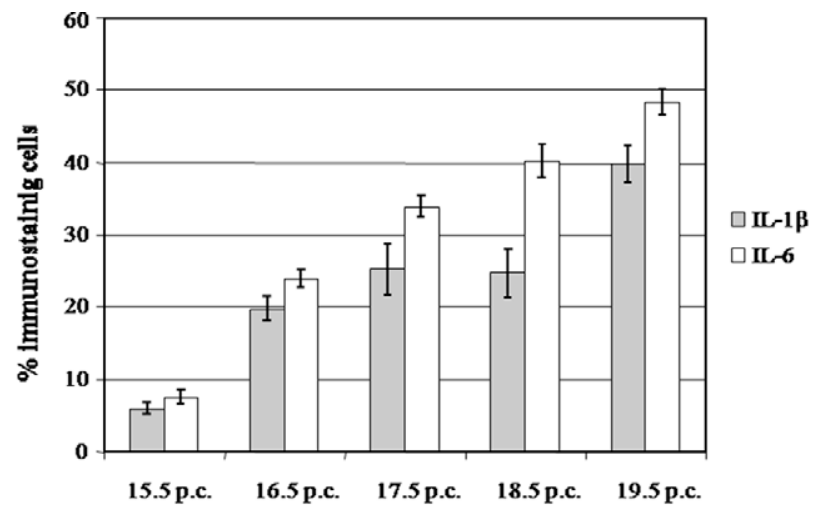

\begin{tabular}{|c|c|c|c|c|c|c|}
\hline & & E-15.5p.c. & E-16.5p.c. & E-175p.c. & E-18_5 p.c. & E-195 p.c. \\
\hline \multirow[t]{2}{*}{$\mathbf{A}$} & L-1; & $230.7 \pm 295$ & $784 \pm 63.8$ & $10052 \pm 141.1$ & $990 \pm 134.4$ & $1592 \pm 1042$ \\
\hline & II-6 & $3015 \pm 35.8$ & $948.75 \pm 50.6$ & $1305.5 \pm 54.4$ & $1604.7 \pm 87.8$ & $1929 \pm 68$ \\
\hline \multirow[t]{2}{*}{$\mathbf{B}$} & 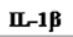 & $5.77 \%$ & $19.60 \%$ & $25.13 \%$ & $24.75 \%$ & $39.8 \%$ \\
\hline & II- 6 & $753 \%$ & $23.7 \%$ & $33.76 \%$ & $40.12 \%$ & $48.22 \%$ \\
\hline
\end{tabular}

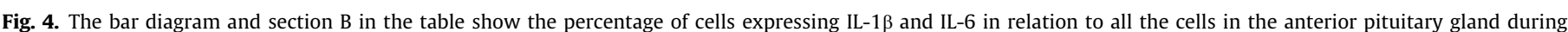

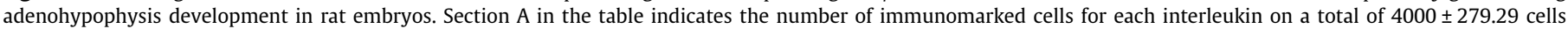

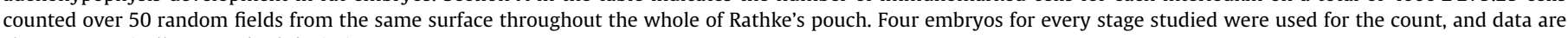
shown numerically \pm standard deviation.

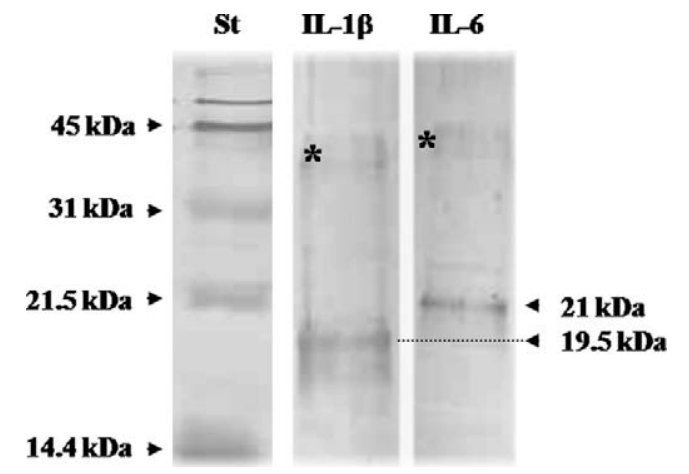

Fig. 5. Western-blot analysis of interleukins from 19.5-day p.c. rat embryo pituitary glands shows immunostained bands of $19.5 \mathrm{kDa}$ with the IL- $1 \beta$ antibody and $21 \mathrm{kDa}$ with the IL- 6 antibody in relation to the protein standards employed (St.). Asterisks indicate weak additional bands for IL-1 $\beta$ and IL- 6 between 45 and $31 \mathrm{kDa}$, which probably correspond to proforms of these interleukins.

cell lines producing and releasing different hormones; cytokines expressed by these cells could play a role in controlling these processes.
4.1. Could IL-1 $\beta$ and IL-6 have an influence on hormonal release and cell differentiation during pituitary development?

It is not clear what mechanisms are involved in anterior pituitary differentiation during development. It has been suggested that hypothalamic release factors could have an influence on this process [49-52]; nevertheless, embryonic pituitary cells can differentiate to LH-secreting cells in the absence of these factors [53]. In addition, extra-hypothalamic factors could have an influence on cell differentiation in the adenohypophysis; for instance, it is known that glucocorticoids stimulate differentiation of $\mathrm{GH}$ and PRL cells in vitro [54,55] and insulin seems to induce gonadotropic differentiation in cultures of embryonic rat adenohypophyseal cells [56].

Data does not exist concerning the role played by interleukins in the differentiation of anterior pituitary cells during embryonic development, although the functional role of IL-1 $\beta$ and IL- 6 on the hypothalamus-pituitary axis is well-known in adults; these interleukins are expressed in certain anterior pituitary cell lines, and it is known that primary cultures of rat pituitary cells respond to IL- $1 \beta$ by an increase in the secretion of ACTH, LH, GH and TSH, 

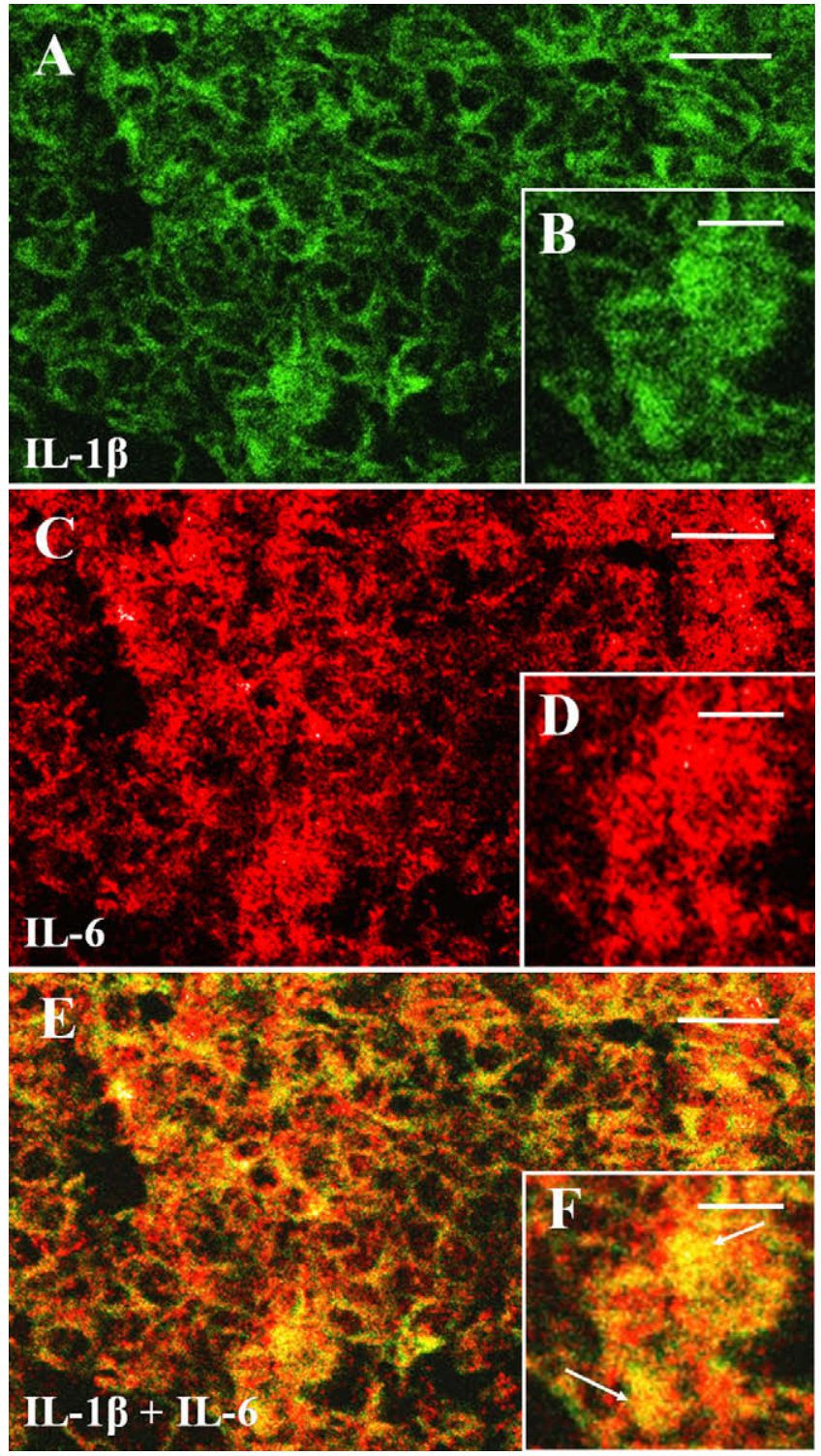

Fig. 6. Double immunolabelling for IL-1 $\beta$ and IL-6. A and B, Histological section of 18.5 days p.c. rat embryo showing IL- $1 \beta$ positive cells (green). $C$ and $D$ : The same section shows abundant IL-6 positive cells (red). E and F: Superposition of images A and $C$ and $B$ and $D$ shows adenohypophyseal cells (yellow) expressing IL-1 $\beta$ and IL-6 at the same time (arrows). Scale bar in A, C and E, $10 \mu \mathrm{m}$; in B, D and F, $5 \mu \mathrm{m}$.

whilst IL-6 stimulates the liberation of PRL, GH, FSH and LH [1,5759].

Likewise, little is known about the expression and function of interleukins during the embryonic and fetal periods. It has been demonstrated that the IL-6 receptor, LIF-receptor and cytokinedependent gp130 are present in human fetal pituitaries, and that IL-6 and LIF stimulate the secretion of ACTH and GH in primary fetal pituitary cell cultures [33]. Furthermore, it is known that most pituitary hormones begin to be produced during the fetal period: ACTH cells are the first to differentiate in 15.5-day p.c. rat embryo anterior pituitary; afterwards, at day 17 p.c. TSH cell differentiation occurs, followed by the differentiation of gonadotrophic cells at day 18 p.c. GH cells at day 19 p.c. and, finally, mammotrophic cells at day 19.5 p.c. [60-64]. Given the coincidence in time between cytokine expression detected by us and anterior pituitary functional differentiation during development, IL-1 $\beta$ and IL-6 might influence either the latter or hormonal release, as in adults. Here it has been shown that prenatal injection of IL-6 causes hormonal disorders after birth, such as obesity, hyperandrogenism and an increase in corticosterone response to stress in rats [35].

Although there are no direct references to the role played by IL$1 \beta$ and IL- 6 in pituitary cell differentiation, important evidence exists concerning that of LIF and other gp130-family cytokines in this process; it has been demonstrated that transgenic overexpression of LIF in the pituitary gland causes an increase in the number of ACTH-secreting cells, Rathke's cysts and Cushing's syndrome $[65,66]$, which suggests that IL-6 and/or other cytokines from the same family could act in a similar way by means of their common transmembrane receptor gp130. In addition, it is known that the administering of lipopolysaccharidases or infections due to gramnegative bacteria inducing high levels of IL-1 $\beta$ and IL-6, produce neuroendocrine alterations during the perinatal period $[34,36,67]$. Such findings indicate that these cytokines may play an important role both in normal development as well as in anterior pituitary prenatal pathogenesis.

\subsection{Are IL-1 $\beta$ and IL-6 involved in pituitary cell proliferation during development?}

During embryonic development, there is notable cellular proliferation in the anterior pituitary, commencing at day 15.5 p.c. in its most ventral and rostral portions, and continuing in later stages until occupying the whole of the pars anterior [68,69]. This proliferative growth coincides spatio-temporally with the IL-1 $\beta$ and IL-6 expression we detected. Although there is no data to establish the effect interleukins have on anterior pituitary cell proliferation during development, it is known that IL-1 and IL-6 influence, both "in vivo" and "in vitro", the growth of certain normal adenohypophysis cell lines [17,70], as well as cells proceeding from pituitary adenomas [14,15]. More recently, we observed that, in vitro, immunosuppression of IL-6 inhibits cellular proliferation and stimulates cellular apoptosis in pituitary cells [11], and it has been demonstrated that small doses of IL-6 stimulate growth in human pituitary cell line HP75, whilst large doses inhibit this process [18]. These results indicate that interleukins might play a part in controlling anterior pituitary growth, and the prenatal expression that we detected could represent a reflection of this control during normal development of the pituitary gland.

\subsection{Possible interaction between $I L-1 \beta$ and $I L-6$ in the developing pituitary gland}

In our study we found a great similarity in both the spatial and temporal distribution patterns of IL-1 $\beta$ and IL-6 in adenohypophysis; for this reason, we performed double immunolabelling in order to determine whether there are pituitary cells producing both interleukins at the same time during embryonic development. In this context, we have found that many pituitary cells express IL$1 \beta$ and IL- 6 simultaneously, which may suggest that IL-1 $\beta$ induces IL-6 expression.

Interaction between IL-1 $\beta$ and IL-6 has been observed in cultures of human pituitary cells from adenomas and in normal adult rat pituitary cells; in these studies, it has been shown that IL- $1 \beta$ is able to induce an increase in the release of IL-6 [71-74]. Moreover, release and hypophyseal expression of IL-6 are considerably reduced in mutant mice for IL-1 $\beta$ [75]. It has also been demonstrated that IL- $1 \beta$ increases the production of IL- 6 in cultures of rat folliculo-stellate cells [76]; these cells are considered a source of organspecific stem cells in the anterior pituitary gland [77,78], and they have been shown to be major producers of IL-6 in the adult pituitary [79]. These data, along with the similarity in the time-space expression of IL- $1 \beta$ and IL-6, and the coexpression of both interleu- 
kins in pituitary cells detected by us, suggest that IL-1 $\beta$ could exert a control on IL-6 expression during embryonic development, similarly to adult folliculo-stellate cells.

To summarise, our study describes IL-1 $\beta$ and IL-6 expression during pituitary gland development in rat embryos. Given the importance that IL-1 $\beta$ and IL- 6 have regarding auto or paracrine control of adenohypophysis pituitary secretion and their possible influence on pituitary growth and tumor formation, this study represents an initial step towards understanding the role played by these interleukins during anterior pituitary organogenesis.

\section{Acknowledgment}

We thank Prof. David Rixham for the linguistic revision of the text.

\section{References}

[1] Ray D, Melmed S. Pituitary cytokine and growth factor expression and action. Endocr Rev 1997;18:206-28.

[2] Turnbull AV, Rivier CL. Regulation of the hypothalamic-pituitary-adrenal axis by cytokines: actions and mechanisms of action. Physiol Rev 1999;79:1-71.

[3] Koenig JI, Snow K, Clark BD, Toni R, Cannon JG, Shaw AR, et al. Intrinsic pituitary interleukin- $1 \beta$ is induced by bacterial lipopolysaccharide. Endocrinology 1990;126:3053-8.

[4] Kurotani R, Yasuda M, Oyama K, Egashira N, Sugaya M, Teramoto A, et al. Expression of interleukin-6, interleukin-6 receptor (gp80), and the receptor's signal-transducing subunit (gp130) in human normal pituitary glands and pituitary adenomas. Mod Pathol 2001;14:791-7.

[5] Jin L, Tsumanuma I, Ruebel KH, Bayliss JM, Lloyd RV. Analysis of homogeneous populations of anterior pituitary folliculostellate cells by laser capture microdissection and reverse transcription-polymerase chain reaction. Endocrinology 2001;142:1703-9.

[6] Takao T, Culp SG, Newton RC, De Souza EB. Type I interleukin-1 receptors in the mouse brain-endocrine-immune axis labelled with [125I] recombinant human interleukin-1 receptor antagonist. J Neuroimmunol 1992;41:51-60.

[7] Marquette C, Van Dam AM, Ban E, Laniece P, Crumeyrolle-Arias M, Fillion C et al. Rat interleukin- $1 \beta$ binding sites in rat hypothalamus and pituitary gland. Neuroendocrinology 1995;62:362-9.

[8] French RA, Zachary JF, Dantzer R, Frawley LS, Chizzonite R, Parnet P, et al Dual expression of p80 type I and p68 type II interleukin-I receptors on anterior pituitary cells synthesizing growth hormone. Endocrinology 1996;137:4027-36.

[9] Hanisch A, Dieterich KD, Dietzmann K, Ludecke K, Buchfelder M, Fahlbusch R, et al. Expression of members of the interleukin- 6 family of cytokines and their receptors in human pituitary and pituitary adenomas. J Clin Endocrinol Metab 2000;85:4411-4.

[10] Gautron L, Lafon P, Tramu G, Laye S. In vivo activation of the interleukin-6 receptor/gp130 signaling pathway in pituitary corticotropes of lipopolysaccharide-treated rats. Neuroendocrinology 2003;77:32-43.

[11] Carretero J, Martín-Clavijo A, Vázquez G, Somalo J, Rubio M, Sánchez F, et al. Effects of in vitro immunosuppression of interleukin 6 on the proliferation of rat hypophyseal cells. Eur J Anat 1999;3:137-43.

[12] Velkeniers B, Vergani P, Trouillas J, D’Haens J, Hooghe RJ, Hooghe-Peters EL. Expression of IL- 6 mRNA in normal rat and human pituitaries and in human pituitary adenomas. J Histochem Cytochem 1994;42:67-76.

[13] Green VL, Atkin SL, Speirs V, Jeffreys RV, Landolt AM, Mathew B, et al. Cytokine expression in human anterior pituitary adenomas. Clin Endocrinol 1996;45:179-85.

[14] Arzt E, Buric R, Stelzer G, Stalla J, Sauer J, Renner U, et al. Interleukin involvement in anterior pituitary cell growth regulation: effects of IL-2 and IL6. Endocrinology 1993;132:459-67.

[15] Pereda MP, Goldberg V, Chervin A, Carrizo G, Molina A, Andrada J, et al. Interleukin-2 (IL-2) and IL-6 regulate $c$-fos protooncogene expression in human pituitary adenoma explants. Mol Cell Endocrinol 1996;124:33-42.

[16] Giacomini D, Acuña M, Gerez J, Nagashima AC, Silberstein S, Páez-Pereda M, et al. Pituitary action of cytokines: focus on BMP-4 and gp130 family. Neuroendocrinology 2007;85:94-100.

[17] Arzt E, Paez Pereda M, Costas M, Sauer J, Renner U, Holsboer F, et al. Cytokine expression and molecular mechanisms of their auto/paracrine regulation of anterior pituitary function and growth. Ann NY Acad Sci 1998;840:525-31.

[18] Borg SA, Kerry KE, Baxter L, Royds JA, Jones TH. Expression of interleukin-6 and its effects on growth of HP75 human pituitary tumour cells. J Clin Endocrinol Metab 2003;88:4938-44.

[19] Onofri C, Carbia Nagashima A, Schaaf L, Feirer M, Lohrer P, Stummer W, et al. Estradiol stimulates vascular endothelial growth factor and interleukin-6 in human lactotroph and lactosomatotroph pituitary adenomas. Exp Clin Endocrinol Diabetes 2004;112:18-23.

[20] Besedovsky HO, del Rey A. Immune-neuro-endocrine interactions: facts and hypotheses. Endocr Rev 1996;17:64-102.
[21] Harbuz MS, Stephanou A, Sarlis N, Lightman SL. The effects of recombinant human interleukin (IL)- $1 \alpha$, IL-1 $\beta$ or IL- 6 on hypothalamo-pituitary-adrenal axis activation. J Endocrinol 1992;133:349-55.

[22] Rivier C, Rivest S. Mechanisms mediating the effects of cytokines on neuroendocrine functions in the rat. Ciba Found Symp 1993;172:204-20.

[23] Kalra PS, Edwards TG, Xu B, Jain M, Kalra SP. The anti-gonadotropic effects of cytokines: the role of neuropeptides. Domest Anim Endocrinol 1998; 15:321-32

[24] Dondi D, Limonta P, Montagnani Marelli M, Piva F. Mechanism of action of interleukin-1 in modulating gonadotropin secretion. In vivo and in vitro studies. Biol Signals Recept 1998;7:55-60.

[25] Spangelo BL, Judd AM, Isakson PC, McLeod RM. Interleukin-6 stimulates anterior pituitary hormone release in vitro. Endocrinology 1989;125:575-7.

[26] Yamaguchi M, Matsuzaki N, Hirota K, Miyake A, Tanizawa O. Interleukin 6 possibly induced by interleukin $1 \beta$ in the pituitary gland stimulates the release of gonadotropins and prolactin. Acta Endocrinol (Copenh) 1990;122:201-5.

[27] Thiele JO, Lohrer P, Schaaf L, Feirer M, Stummer W, Losa M, et al. Functional in vitro studies on the role and regulation of interleukin-6 in human somatotroph pituitary adenomas. Eur J Endocrinol 2003;149:455-61.

[28] Zolti M, Ben-Rafael Z, Meirom R, Shemesh M, Bider D, Mashiach S, et al. Cytokine involvement in oocytes and early embryos. Fertil Steril 1991;56:265-72.

[29] Jelaso AM, Acevedo S, Dang T, Lepere A, Ide CF. Interleukin-1 $\beta$ and its type 1 receptor are expressed in developing neural circuits in the frog, Xenopus laevis. J Comp Neurol 1998;394:242-51.

[30] Jelaso AM, Delong C. NGF and IL-1 $\beta$ are co-localized in the developing nervous system of the frog, Xenopus laevis. Int J Dev Neuroscience 2005;23:575-86.

[31] de la Mano A, Gato A, Alonso MI, Carnicero E, Martín C, Moro JA. Role of interleukin-1 $\beta$ in the control of neuroepithelial proliferation and differentiation of the spinal cord during development. Cytokine 2007;37:128-37.

[32] Dame JB, Juul SE. The distribution of receptors for the pro-inflammatory cytokines interleukin (IL)-6 and IL-8 in the developing human fetus. Early Hum Dev 2000;58:25-39.

[33] Shimon I, Yan X, Ray DW, Melmed S. Cytokine-dependent gp130 receptor subunit regulates human fetal pituitary adrenocorticotropin hormone and growth hormone secretion. J Clin Invest 1997;100:357-63.

[34] Gotz F, Dorner G, Malz U, Rohde W, Stahl F, Poppe I, et al. Short- and long-term effects of perinatal interleukin-1 $\beta$-application in rats. Neuroendocrinology 1993:58:344-51.

[35] Dahlgren J, Nilsson C, Jennische E, Ho HP, Eriksson E, Niklasson A, et al. Prenatal cytokine exposure results in obesity and gender-specific programming. Am J Physiol Endocrinol Metab 2001;281:E326-34.

[36] Shanks N, Larocque S, Meaney J. Neonatal endotoxin exposure alters the development of the hypothalamic-pituitary-adrenal axis: early illness and later responsivity to stress. J Neurosci 1995;15:376-84.

[37] Somogyi P. Takagi $\mathrm{H}$. A note on the use of picric acid-paraformaldehydeglutaraldehyde fixative for correlated light and electron microscopic immunocytochemistry. Neuroscience 1982;7:1779-83.

[38] Hashimoto H, Ishikawa $H$, Kusakabe M. Three-dimensional analysis of the developing pituitary gland in the mouse. Dev Dyn 1998;212:157-66.

[39] May LT, Ghrayeb J, Santhanam U, Tatter SB, Sthoeger Z, Helfgott DC, et al. Synthesis and secretion of multiple forms of $\beta 2$-interferon/B-cell differentiation factor 2/hepatocyte-stimulating factor by human fibroblasts and monocytes. J Biol Chem 1988;263:7760-6.

[40] Chauvet N, Palin K, Verrier D, Poole S, Dantzer R, Lestage J. Rat microglial cells secrete predominantly the precursor of interleukin-1 $\beta$ in response to lipopolysaccharide. Eur J Neurosci 2001;14:609-17.

[41] Arzt E, Stelzer G, Renner U, Lange M, Müller OA, Stalla GK. Interleukin-2 and interleukin-2 receptor expression in human corticotrophic adenoma and murine pituitary cell cultures. J Clin Invest 1992;90:1944-51.

[42] Raber J, Sorg O, Horn TF, Yu N, Koob GF, Campbell IL, et al. Inflammatory cytokines: putative regulators of neuronal and neuro-endocrine function. Brain Res Brain Res Rev 1998;26:320-6.

[43] Suliman ME, Royds JA, Baxter L, Timperley WR, Cullen DR, Jones TH. IL-8 mRNA expression by in situ hybridisation in human pituitary adenomas. Eur J Endocrinol 1999;140:155-8.

[44] Auernhammer C], Melmed S. Interleukin-11 stimulates proopiomelanocortin gene expression and adrenocorticotropin secretion in corticotroph cells: evidence for a redundant cytokine network in the hypothalamo-pituitaryadrenal axis. Endocrinology 1999;140:1559-66.

[45] Nagai Y, Nochi T, Watanabe K, Watanabe K, Aso H, Kitazawa H, et al. Localization of interleukin-18 and its receptor in somatotrophs of the bovine anterior pituitary gland. Cell Tissue Res 2005;322:455-62.

[46] Nagai Y, Watanabe K, Aso H, Ohwada S, Muneta Y, Yamaguchi T. Cellular localization of IL-18 and IL-18 receptor in pig anterior pituitary gland. Domest Anim Endocrinol 2006;30:144-54.

[47] Wang N, Sugama S, Conti B, Teramoto A, Shibasaki T. Interleukin-18 mRNA expression in the rat pituitary gland. J Neuroimmunol 2006;173:117-25.

[48] Chen L, Liu Y, Hou Y, Kato Y, Sano H, Kanno T. Expression and structure of interleukin 4 receptor (IL-4R) complex in human invasive pituitary adenomas. Neurosci Lett 2007:417:30-5.

[49] Chatelain A, Dubois MP, Dupouy JP. Hypothalamus and cytodifferentiation of the foetal pituitary gland. Study in vivo. Cell Tissue Res 1976;169:335-44.

[50] Begeot M, Hemming FJ, Aubert ML, Dubois PM. Differentiation of pituitary cells in culture. Ann Endocrinol (Paris) 1987:48:367-77. 
[51] Heritier AG, Dubois PM. Influence of thyroliberin on the rat pituitary cell type differentiation: an in vitro study. Endocrinology 1993;132:634-9.

[52] Heritier AG, Dubois PM. Re-evaluation of gonadotropin-releasing hormone $(\mathrm{GnRH})$ action on pituitary cell differentiation with special regard to its effect on LH and TSH cell types. J Neuroendocrinol 1994;6:33-7.

[53] Nemeskeri A, Kurcz M, Halasz B. Changes in hypophyseal luteinizing hormone (LH) content during fetal and early postnatal life, and capacity of fetal and early postnatal pituitaries to synthesize and release LH in vitro. Neuroendocrinology 1984;38:393-6.

[54] Hemming FJ, Aubert ML, Dubois PM. Differentiation of fetal rat somatotropes in vitro: effects of cortisol,3,5,3'-triiodothyronine, and glucagon, a light microscopic and radioimmunological study. Endocrinology 1988;123:1230-6.

[55] Sato K, Watanabe YG. Corticosteroids stimulate the differentiation of growth hormone cells but suppress that of prolactin cells in the fetal rat pituitary. Arch Histol Cytol 1998;61:75-81.

[56] Begeot M, Dubois MP, Dubois PM. Comparative study in vivo and in vitro of the differentiation of immunoreactive gonadotropic cells in fetal rat anterior pituitary. Neuroendocrinology 1983;37:52-8.

[57] Mainardi GL, Saleri R, Tamanini C, Baratta M. Effects of interleukin-1- $\beta$, interleukin-6 and tumor necrosis factor- $\alpha$, alone or in association with hexarelin or galanin, on growth hormone gene expression and growth hormone release from pig pituitary cells. Horm Res 2002;58:180-6.

[58] Gong FY, Deng JY, Shi YF. Stimulatory effect of interleukin-1 $\beta$ on growth hormone gene expression and growth hormone release from rat GH3 cells. Neuroendocrinology 2005;81:217-28.

[59] Gong FY, Shi YF, Deng JY. The regulatory mechanism by which interleukin-6 stimulates GH-gene expression in rat GH3 cells. J Endocrinol 2006;190:397-406.

[60] Setalo G, Nakane PK. Functional differentiation of the fetal anterior pituitary cells in the rat. Endocrinol Exp 1976;10:155-66.

[61] Begeot M, Dupouy JP, Dubois MP, Dubois PM. Immunocytological determination of gonadotropic and thyrotropic cells in fetal rat anterior pituitary during normal development and under experimental conditions. Neuroendocrinology 1981;32:285-94.

[62] Taniguchi Y, Kominami R, Yasutaka S, Kawarai Y. Proliferation and differentiation of pituitary corticotrophs during de fetal and postnatal period: a quantitative immunocytochemical study. Anat Embryol 2000;201:229-34

[63] Taniguchi Y, Yasutaka S, Kominami R, Shinohara H. Proliferation and differentiation of thyrotrophs in the pars distalis of the rat pituitary gland during the fetal and postnatal period. Anat Embryol 2001;203:249-53.

[64] Taniguchi Y, Yasutaka S, Kominami R, Shinohara H. Proliferation and differentiation of pituitary somatotrophs and mammotrophs during late fetal and postnatal period. Anat Embryol 2001;204:469-75.

[65] Akita S, Readhead C, Stefaneanu L, Fine J, Tampanaru-Sarmesiu A, Kovacs K, et al. Pituitary-directed leukemia inhibitory factor transgene forms Rathke's cleft cysts and impairs adult pituitary function. a model for human pituitary Rathke's cysts. J Clin Invest 1997;99:2462-9.

[66] Yano H, Readhead C, Nakashima M, Ren SG, Melmed S. Pituitary-directed leukemia inhibitory factor transgene causes Cushing's syndrome: neuroimmune-endocrine modulation of pituitary development. Mol Endocrinol 1998; 12:1708-20.

[67] Bumiller A, Götz F, Rohde W, Döner G. Effects of repeated injections of interleukin 1 or lipopolysaccharide on the HPA axis in the newborn rat. Cytokine 1999;11:225-30.

[68] Kaufman MH. The atlas of mouse development. first ed. Cambridge: University Press; 1992.

[69] Taniguchi Y, Yasutaka S, Kominami R, Shinohara H. Proliferation and differentiation of rat anterior pituitary cells. Anat Embryol 2002;206:1-11.

[70] Callahan TA, Piekut DT. Differential Fos expression induced by IL-1 $\beta$ and IL-6 in rat hypothalamus and pituitary gland. J Neuroimmunol 1997;73:207-11.

[71] Spangelo BL, Judd AM, Isakson PC, McLeod RM. Interleukin-1 stimulates interleukin-6 release from rat anterior pituitary cells in vitro. Endocrinology 1991;128:2685-92.

[72] Spangelo BL, Jarvis WD, Judd AM, McLeod RM. Induction of interleukin-6 release by interleukin-1 in rat anterior pituitary cells in vitro: evidence for an eicosanoid-dependent mechanism. Endocrinology 1991;129:2886-94.

[73] Jones TH, Kennedy RL, Justice SK, Price A. Interleukin-1 stimulates the release of interleukin-6 from cultured human pituitary adenoma cells. Acta Endocrinol (Copenh) 1993;128:405-10.

74] Spangelo BL, Farrimond DD, Pompilius M, Bowman KL. Interleukin-1 $\beta$ and thymic peptide regulation of pituitary and glial cell cytokine expression and cellular proliferation. Ann NY Acad Sci 2000;917:597-607.

15] Chida D, Imaki T, Suda T, Iwakura Y. Involvement of corticotropin-releasing hormone- and interleukin (IL)-6-dependent proopiomelanocortin induction in the anterior pituitary during hypothalamic-pituitary-adrenal axis activation by IL-1 $\alpha$. Endocrinology 2005;146:5496-502.

[76] Bilezikjian LM, Leal AM, Blount AL, Corrigan AZ, Turnbull AV, Vale WW. Rat anterior pituitary folliculostellate cells are targets of interleukin-1 $\beta$ and major source of intrapituitary follistatin. Endocrinology 2003;144:732-40.

[77] Inoue K, Mogi C, Ogawa S, Tomida M, Miyai S. Are folliculo-stellate cells in the anterior pituitary gland supportive cells or organ-specific stem cells? Arch Physiol Biochem 2002;110:50-3.

[78] Mogi C, Miyai S, Nishimura Y, Fukuro H, Yokoyama K, Takaki A, et al. Differentiation of skeletal muscle from pituitary folliculo-stellate cells and endocrine progenitor cells. Exp Cell Res 2004;292:288-94.

[79] Lohrer P, Gloddek J, Nagashima AC, Korali Z, Hopfner U, Pereda MP, et al Lipopolysaccharide directly stimulates the intrapituitary interleukin-6 production by folliculostellate cells via specific receptors and the p38 $\alpha$ mitogen-activated protein kinase/nuclear factor- $\kappa B$ pathway. Endocrinology 2000;141:4457-65. 